\title{
PENERAPAN MODEL PEMBELAJARAN GROUP INVESTIGATION DI SEKOLAH MENENGAH ATAS DALAM LIMA TAHUN TERAKHIR (2015-2020): STUDI LITERATURE PADA MATA PELAJARAN EKONOMI
}

\author{
Martinus Erwin Raharja \\ S1 PendidikanEkonomi, FakultasEkonomi, UniversitasNegeri Surabaya \\ Email: martinusraharja@mhs.unesa.ac.id \\ Retno Mustika Dewi \\ Jurusan Pendidikan Ekonomi, FakultasEkonomiUniversitasNegeri Surabaya \\ Email: retnomustika@unesa.ac.id
}

\begin{abstract}
Abstrak
Rendahnya hasil belajar merupakan suatu masalah yang dihadapi siswa sekolah menengah atas khususnya pada mata pelajaran ekonomi. Tujuan dari studi literatur ini adalah untuk menganalisis penerapan group investigation sebagai suatu inovasi model pembelajaran pada mata pelajaran ekonomi sehingga meningkatkan hasil belajar siswa. Studi literatur ini diperoleh dari penulusuran artikel penelitian ilmiah rentang tahun 2015-2020 dengan menggunakan google schoolar. Dari berbagai literatur tentang penerapan model group investigation di tingkat SMA pada pelajaran ekonomi terdapat 9 artikel yang telah diberi identification, screening, eliglibility yang relevan dengan tujuan penelitian. Hasil studi literatur menyimpulkan bahwa model pembelajaran group invetigation pada mata pelajaran ekonomi berdampak positif untuk meningkatkan hasil belajar siswa. Hasil analisis menunjukkan siswa yang menggunakan metode group investigation mengalami peningkatan hasil belajar atau mendapatkan peningkatan yang baik saat proses pembelajaran siklus ke dua maupun ketiga.
\end{abstract}

Kata Kunci: Group investigation, hasil belajar, SMA, ekonomi.

\begin{abstract}
Education became a necessity to ensure the development of each nation, without which there was an education, man could not improve his quality. Learning model group investigation in the learning process. The purpose of this literature study is to analyze the application of the study group investigation model on economic subjects to increase the students' study results. This literature study was obtained from the book of scientific research in 2015-2020 through Google schoolar. Many of the literature on the application of the high school model group investigation on economic subjects contain 9 articles that have been carried out identification, citizenship, eliglibility that are relevant to the study's purpose. Literature studies conclude the implementation of the invetigation group learning model on economic subjects are positive for improving student results. Analysis indicates that students studying in an investigation group experienced a significant increase in learning results or an improvement in the second or third cycle learning process.
\end{abstract}

Keywords: Group Investigation, Learning Outcomes, Economics.

\section{PENDAHULUAN}

Pendidikan adalah suatu bagian yang sangat penting bagi sebuah negara. Pendidikan dapat menjadi sebagain sebuah proses perubahan sikap seseorang dalam usaha untuk meningkatkan upaya dari pengajaran dan pelatihan (Sugihartono, 2012). Bila tidak ada pendidikan, manusia tidak dapat meningkatkan kualitasnya, sehingga sama seperti manusia jaman dahulu yang sangat tertinggal kualitas hidupnya. Menurut (Aminah dan Salihati, 2012) Pendidikan merupakan suatu hal yang sangat penting bagi manusia agar menjadi lebih berkualitas. Manusia harus menyesuaikan diri pada kemajuan zaman, kemajuan pendidikan, dan kemajuan teknologi. Salah satu cara dalam meningkatkan kualitas pendidikan yaitu perlunya mensinergikan komponen-komponen dalam proses belajar mengajar dikelas diantaranya, proses pembelajaran yang diterapkan yang cocok untuk meningkatkan pemahaman materi pelajaran sehingga mampu menaikkan hasil kemampuan siswa (Rahayuni, 2016).

Berdasarkan hal diatas, maka diperlukan suatu metode yang bisa melibatkan peran serta para siswa secara penuh sehingga meningkatkan hasil dalam pembelajaranya. Karena sebaiknya proses pembelajaran tidak hanya 
berupaya untuk mendapatkan dan ilmu sebanyakbanyaknya, namun juga meningkatkan kemampuan siswa dalam berinteraksi sosial, menerima saran dari orang lain yang mempunyai kemampuan berpikir dan cara pandang yang berbeda pada materi yang sedang ditempuh. Maka model pembelajaran Group Investigation (GI) cocok digunakan dalam pembelajaran ekonomi. GI adalah suatu model pembelajaran yang lebih menekankan pada pilihan dan kontrol siswa daripada menerapkan teknik-teknik pengajaran di ruang kelas. Selain itu juga memadukan prinsip belajar demokratis dimana siswa terlibat secara aktif dalam kegiatan pembelajaran, baik dari tahap awal sampai akhir pembelajaran termasuk didalamnya siswa mempunyai kebebasan untuk memilih materi yang akan dipelajari sesuai dengan topik yang sedang dibahas. Hal tersebut didukung dengan penelitian yang sudah dilakukan Priyono (2017) yang menyimpulkan bahwa dengan menggunakan model pembelajaran GI, ketuntasan belajar siswa mencapai 92\%, hal ini menjelasakan bahwa dengan penerapan model pembalajaran GI, mampu meningkatkan hasil belajar siswa. Penelitian tersebut diperkuat dengan penelitian oleh Fatmawati (2019) yang menyimpulkan bahwa penerapan model GI mampu meningkatkan pengaruh positif diantaranya motivasi belajar siswa kelas $\mathrm{X}$, sehingga mampu meningkatkan hasil belajar.

Selain beberapa penelitian yang telah dilakukan menunjukkan model pembelajaran GI mampu meningkatkan hasil belajar siswa khususnya pada mata pembelajaran ekonomi, beberapa ahli juga menjelaskan tentang kelebihan dari model pembelajaran GI. Menurut Wena (2012) GI ialah salah satu metode yang lebih ditujukan pada keaktifan dan patisipasi dari para peserta untuk lebih menggali lagi informasi dan materi sendiri pelajaran yang akan dipelajari,serperti di internet atau perpustakaan. Metode ini dapat melatih para peserta agar lebih mandiri dan meningkatkan komunikasi satu dengan lainya. Hal tersebut sependapat dengan Rusman (2011) yang menjelasakan MODEL GI membuat para peserta terlibat dari penyusunan rencana menentukan topik.hal ini bisa memberikan peluang bagi para peserta untuk lebih memahami dan lebih dalam lagi pada materi yang didapatkan.

(Trianto, 2009) juga menjelaskan GI merupakan model belajar mengajar kooperatif yang cukup kompleks dan cukup rumit untuk dilakukan. Dalam pembelajaran para siswa harus lebih terlibat lagi untuk menetukan rencana topik yang akan dipilih dan dan jalan dari pemahanman mereka. Pembelajaran ini memerlukan pengelolaan kelas yang sulit dibandingkan pembelajaran yang berpokok pada guru dan memerlukan komunikasi antara siswa dan guru.(Adiasti, 2016) menambahkan bahwa GI dapat meningkatkan keakrapan dalam suatu hubungan, percaya, peduli pada orang lain. GI membuat belajar mengajar menjadi lebih menyenangkan, menarik, hubungan satu dengan uang lain jadi lebih baik, memiliki kemampuan yang baik,dan bisa memahami topik yang di diskusikan.

Menurut (Sangadji, 2016)model belajar mengajar GI memiliki beberapa keunggulan yaitu:(1) siswa yang mengikuti model GI akan lebih menyukai dan lebih aktif lagi dalam memberikan pendapatnya; 2) mereka bisa memperhatikan cara bicara mereka sendiri secara naturaldan dalam penerapan model GI dapat bekerja sama; (3)agar siswa bisa lebih bisa bekerjasama serta dapat meningkatkan hubungan interaksi social satu dengan yang lain;(4) bila ada siswa yang memiliki latar belakang lebih rendah bisa berpartisipasi dan mengikuti lebih kooperatif dalam kegiatan belajar mengajar dan berkomunikasi dengan baik anatara satu dengan yang lain;(5) GI bisa lebih mendukung para siswa untuk berpatisipasi agar lebih aktif sehingga dapat meningkatkan pengetahuan; (6) GI memberikan kesempatan pada guru agar dapat lebih formal agarlebih mudah melakukan pendekatan dan bantuan kepada siswa;(7) GI bisa meningkatkan prestasi dan performa pada siswa. Sedangkan GI juga memiliki kekurangan diantaranya: (1)hanya sebagian siswa yang terlihat aktif dalam berdiskusi; (2)dalam kelompok belajar masih ada siswa yang sulit disatukan karena masih adanya pertentangan dan perbedaan pendapat; (3)siswa yang belum terbiasa menemukan hal baru akan lebih merasakan kesulitan; (4) ada kesulitan dalam karena adanya bahan bahan ajar yang kurang tersedia.

Dari beberapa keunggulan dan kekurangan dari model GI diatas serta di dukung dengan penelitian yang telah dilakukan, maka arikel ini membahas studi literatur terhadap menerapkan model pembelajaran GI dalam usaha untuk meningkatkan hasil belajar. Studi literatur akan difokus dalam penelitian tingkat SMA pada mata pelajaran ekonomi. Studi literatur ini agar pada pengaplikasian dari model GI dapat di analisis pada mata pelajaran ekonomi agar lebih mengembagkan lagi hasil dari belajar para siswa. Harapan dari studi literatur ini, dapat dijadikan rujukan maupun pandangan guru dalam memilih model pembelajaran dalam upaya dan usaha untuk lebih meningkatkan lagi hasil dari belajar para siswa, khususnya pada mata pelajaran ekonomi. 


\section{METODE}

Studi literatur ini didapat dari beberapa artikel penelitian ilimiah dengan menggunakan Google Schoolar kemudian dilakukan identification, screening, dan eliglibility. Pada proses identification dengan memasukkan "Penerapan Group Investigation" terdapat artikel 160 artikel. Kemudian pada tahan screening dicari artikel pada rentan tahun 2015-2020 terdapat 30 artikel. Pencarian litaratur dipersempit dengan kriteria penelitian dilakukan pada pembelajaran ekonomi terdapat 30 artikel. Kemudian screening kembali yang sesuai dengan topik literatur yaitu mata pelajaran ekonomi terdapat 18 artikel. Selanjutnya pada tahan eligibility pencarian difokuskan pada dua variabel yang akan dibahas yaitu (1) penelitian dilakukan di tingkat SMA dan (2) penelitian menggunakan penelitian tindakan kelas (PTK) sehingga mendapatkan 9 artikel. Dari kriteria tersebut Pencarian literatur, dapat dilihat pada Gambar 2

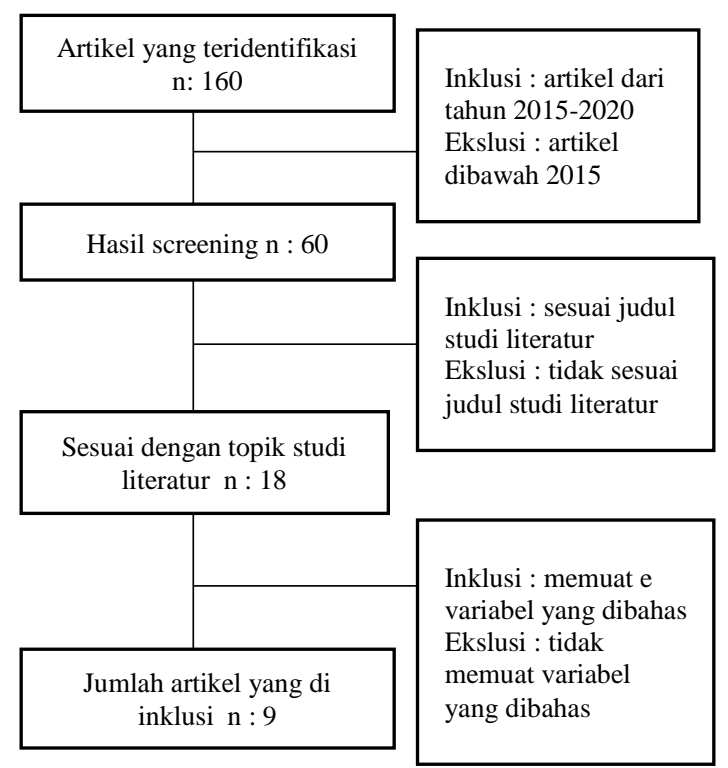

Gambar 2. Flow diagram pencarian literatur

\section{HASIL DAN PEMBAHASAN}

Berdasarkan hasil 680 literatur, setelah dilakukan identification, screening, eliglibility maka di dapat 9 artikel yang relevan dengan kriteria yang telah ditentukan, seperti yang ditunjukan Tabel 1

Tabel 1. Analisis Sintesis Pencarian Literatur

\begin{tabular}{|c|c|c|c|}
\hline No & Author dan Judul & Metode dan Instrumen & Hasil \\
\hline 1 & $\begin{array}{l}\text { (Tisara, 2016)Usaha } \\
\text { Meningkatkan Hasil Dari } \\
\text { Belajar Pada Materi } \\
\text { Permasalahan Ekonomi } \\
\text { Melalui Pelaksanaan } \\
\text { Pembelajaran Kooperatif } \\
\text { Tipe Group Investigation } \\
\text { (GI) Pada Kelas X-6 } \\
\text { SMA Negeri } 1 \text { Krueng }\end{array}$ & $\begin{array}{l}\text { Penilaian Tindakan Kelas, } \\
\text { Observasi dan Hasil Tes }\end{array}$ & $\begin{array}{l}\text { Hasil penelitian menunjukkan bahwa } \\
\text { pada siklus pertama, dari } 21 \text { orang yang } \\
\text { mengikuti tes dari hasil belajar, siswa } \\
\text { yang mendapatkan nilai rerata } 66,67 \text {. } \\
\text { Selanjutnya pada siklus yang kedua } \\
\text { mengalami peningkatan yang cukup } \\
\text { signifikan dengan skor rerata } 80,95 \text {. Hal } \\
\text { yang sama juga terjadi pada aktivitas } \\
\text { siswa selama mengikuti pembelajaran } \\
\text { GI. Pada awal pembelajaran aktivitas } \\
\text { siswa mendapatkan presentase } 62,5 \% \text {, } \\
\text { dan ada peningkatan pada siklus kedua } \\
\text { menjadi } 83,33 \% \text {. }\end{array}$ \\
\hline 2 & $\begin{array}{l}\text { (Haibah, 2016) } \\
\text { Implementasi Model } \\
\text { Pembelajaran Group } \\
\text { Investigation Dengan }\end{array}$ & $\begin{array}{l}\text { Penelitian Tindakan } \\
\text { Kelas, } \\
\text { Angket dan Tes Hasil } \\
\text { Belajar }\end{array}$ & $\begin{array}{l}\text { Hasil penelitian menunjukkan model } \\
\text { pembelajaran GI mampu meningkatkan } \\
\text { pemahaman konsep ekonomi siswa, dan } \\
\text { tes pemehaman konsep mengalami }\end{array}$ \\
\hline
\end{tabular}




\begin{tabular}{|c|c|c|c|}
\hline No & Author dan Judul & Metode dan Instrumen & Hasil \\
\hline & $\begin{array}{l}\text { Permainan Bendera Pintar } \\
\text { Untuk Meningkatkan } \\
\text { Minat Belajar dan } \\
\text { Pemahaman Konsep } \\
\text { Ekonomi Siswa Kelas X } \\
\text { IPA 3, SMA N 1 Jetis } \\
\text { Bantul }\end{array}$ & & $\begin{array}{l}\text { peningkatan dengan skor rerata } 59,375 \\
\text { pada siklus yang pertama, lalu menjadi } \\
87,5 \text { pada siklus kedua. Sementara } \\
\text { untuk minat belajar siswa juga } \\
\text { mengalami peningkatan. Pada siklus } \\
\text { yang pertama siswa mengalami } \\
\text { peningkatan dari } 18,75 \% \text { menjadi } \\
78,125 \% \text {. }\end{array}$ \\
\hline 3 & $\begin{array}{l}\text { (Agustina, } \\
\text { 2018)Meningkatkan Hasil } \\
\text { Belajar Ekonomi Dengan } \\
\text { Menerapkan dari Model } \\
\text { Pembelajaran Group } \\
\text { Investigation (GI) Pada } \\
\text { Siswa Kelas X di SMA } \\
\text { Negeri 1 Jeumpa }\end{array}$ & $\begin{array}{l}\text { Penelitian Tindakan } \\
\text { Kelas, } \\
\text { Tes Hasil Belajar dan } \\
\text { Angket }\end{array}$ & $\begin{array}{l}\text { Hasil penelitian menunjukkan } \\
\text { pembelajaran menggunakan GI } \\
\text { dapatmeningkatkan dari hasil belajar, } \\
\text { hal itu berdasarkan pada siklus yang } \\
\text { pertma pada siswa tuntas dalam } \\
\text { mencapai KKM sebesar } 60 \% \\
\text { sedangkan pada siklus ke dua naik } \\
\text { sebesar } 90 \% \text {. Selain itu pembelajaran } \\
\text { menggunakan GI juga mendapatkan } \\
\text { respon yang baik dengan } 95 \% \text { siswa } \\
\text { menyatakan senang ketika proses } \\
\text { pembelajaran dengan GI. }\end{array}$ \\
\hline 4 & $\begin{array}{l}\text { (Astuti, Y. T., \& } \\
\text { Haryono, } \\
\text { 2017)Implementasi } \\
\text { Metode Brainstorming } \\
\text { Dalam Model Group } \\
\text { Investigation Pada Mata } \\
\text { Pelajaran Ekonomi Untuk } \\
\text { Meningkatkan Keaktifan } \\
\text { dan Hasil Belajar Siswa } \\
\text { Kelas X IPS 3 SMAN 1 } \\
\text { Batu }\end{array}$ & $\begin{array}{l}\text { Penelitian Tindakan } \\
\text { Kelas, Observasi dan Tes } \\
\text { Belajar }\end{array}$ & $\begin{array}{l}\text { Hasil dari GI mampu memberikan } \\
\text { peningkatan yang cukup signifikan, hal } \\
\text { itu terlihat pada siklus yang pertama } \\
\text { mendapatkan skor rerata } 69,63 \text {, untuk } \\
\text { siklus kedua ada peningkatan dengan } \\
\text { skor rerata } 80 \text {. Selain itu model } \\
\text { pembelajaran GI juga mampu } \\
\text { meningkatkan kefektivan siswa dengan } \\
\text { data awal mendapatkan nilai } 63,60 \% \\
\text { dan mengalami peningkatan setelah } \\
\text { pembelajaran dengan GI menjadi } \\
82,31 \% \text {. }\end{array}$ \\
\hline 5 & $\begin{array}{l}\text { (Novitasari, } \\
\text { 2017)Penerapan Metode } \\
\text { Pembelajaran Group } \\
\text { Investigation Dalam } \\
\text { Meningkatkan Prestasi } \\
\text { Belajar Siswa Mata } \\
\text { Pelajaran Ekonomi di } \\
\text { SMA }\end{array}$ & $\begin{array}{l}\text { Penelitian Tindakan } \\
\text { Kelas, } \\
\text { Observasi dan Tes Hasil } \\
\text { Belajar }\end{array}$ & $\begin{array}{l}\text { Hasil penelitian menunjukkan } \\
\text { pembelajaran menggunakan GI mampu } \\
\text { meningkatkan hasil belajar dari skor } \\
\text { rearta } 67,71 \text { meningkat menjadi skor } \\
\text { rerata } 85,44 \text { pada siklus ke dua. }\end{array}$ \\
\hline 6 & $\begin{array}{l}\text { (Umantin, 2017)Aplikasi } \\
\text { Problem Based Learning } \\
\text { dan Group Investigation } \\
\text { Dalam Pembelajaran } \\
\text { Ekonomi di MAN Malang } \\
\text { I }\end{array}$ & $\begin{array}{l}\text { Penelitian Tindakan } \\
\text { Kelas, } \\
\text { Observasi dan Tes Hasil } \\
\text { Belajar. }\end{array}$ & $\begin{array}{l}\text { Hasil penelitian menunjukkan hasil } \\
\text { selama melakukan model pengajaran } \\
\text { dengan GI, adanya kenaikan pada siklus } \\
\text { pertama mendapat skor rerata } 67,56 \\
\text { mengalami peningkatan sebesar } 76,88 \\
\text { pada siklus kedua. }\end{array}$ \\
\hline 7 & $\begin{array}{l}\text { (Priyono, } \\
\text { 2017)Peningkatan Hasil } \\
\text { Belajar Mata Pelajaran } \\
\text { Ekonomi Melalui } \\
\text { Penerapan Model } \\
\text { Pembelajaran Group } \\
\text { Investigation }\end{array}$ & $\begin{array}{l}\text { Penelitian Tindakan } \\
\text { Kelas, } \\
\text { Observasi dan Tes Hasil } \\
\text { Belajar }\end{array}$ & $\begin{array}{l}\text { Hasil penelitian menunjukkan } \\
\text { pembelajaran dengan menggunakan GI } \\
\text { mengalami peningkatan. Hal tersebut } \\
\text { terbukti ketika pada siklus } 1 \text { siswa } \\
\text { memiliki rerata skor } 62 \text {, kemudian } \\
\text { mengalami peningakatan menjadi } \\
\text { 81dan siklus kedua, maupu siklus } \\
\text { ketiga juga mengalami peningkatan } \\
\text { skor menjadi } 92 \text {. }\end{array}$ \\
\hline 8 & $\begin{array}{l}\text { (Idrawati, } \\
\text { 2018)Pembelajaran Group } \\
\text { Investigasi Meningkatkan } \\
\text { Hasil Belajar }\end{array}$ & $\begin{array}{l}\text { Penelitian Tindakan } \\
\text { Kelas, } \\
\text { Tes hasil belajar }\end{array}$ & $\begin{array}{l}\text { Hasil dari penelitian pada model Group } \\
\text { investigation mampu memberikan } \\
\text { peningkatan pada hasil studi siswa } \\
\text { yang pada awal siklusnya memperoleh } \\
\text { skor rerata } 72,65 \text {. Adanya peningkatan } \\
\text { juga pada siklus kedua dengan skor } \\
\text { rerata } 75,03\end{array}$ \\
\hline
\end{tabular}




\begin{tabular}{clll}
\hline No & \multicolumn{1}{c}{ Author dan Judul } & Metode dan Instrumen & \multicolumn{1}{c}{ Hasil } \\
\hline 9 & (Fatmawati, & Penelitian Tindakan & Hasil dari penelitian dapat terlihat \\
& 2019)Peningkatan & Kelas, & bahwa dengan model GI mampu \\
& Pemahaman Pelaku & Observasi dan Tes Hasil & memberikan kenaikan pada hasil belajar \\
& Ekonomi Dalam Kegiatan & Belajar & siswa dengan rerata skor awal yaitu \\
& Ekonomi Menggunakan & & 62,5 adanya kenaikan yaitu skor 88,89 \\
& Pembelajaran Kooperatif & & disiklus yang kedua. \\
& Model Group & & \\
Investigation (GI) Pada & & \\
Siswa. & & \\
\hline
\end{tabular}

Tabel 1 menunjukkan 9 artikel penelitian yang sesuai dengan kriteria studi literatur yaitu penetian PTK dan dilakukan di tingkat SMA pada mata pelajaran ekonomi. Penelitian oleh (Tisara, 2016)menjelaskan pelaksanaan pembelajaran Group Investigation dapat meningkatkan hasilbelajar ekonomi materi masalalah ekonomi pada siswa. Hasil tersebut di dapat ketika penelitian pada siklus I siswa memperoleh nilai 66,67, setelah memperoleh pembelajaran dengan menggunakan GI, sebagian besar ada peningkatan menjadi 80,95. Selain itu,pada penerapan model pembelajaran GI juga menghasilkan peningkatkan. Hal tersebut dibuktikan dari penelitian siklus pertama aktivitas belajar siswa mendapatkan presentase $62,5 \%$, kemudian siklus yang kedua ada peningkatan yang cukup siknifikan yaitu $83,33 \%$. Hal tersebut sejalan dengan (Haibah, 2016)menjelaskan penerapan metode GI dapat memberikan peningkatan pemahaman materi dan minat siswa dalam mempelajari ilmu ekonomi. Data tersebut di dapat ketika penilaian awal skor rerata hanya 59,375pada siklus pertama. Kemudian pada siklus yang kedua mengalami peningkatan juga sebesar 87,5. Selain itu minat siswa dalam belajar ekonomi juga meningkat. Pada penilaian awal minat siswa terhadap pelajaran ekonomi hanya $18,75 \%$ setelah diberi perlakuan model GI, minat belajar siswa meningkat menjadi 78,125\%. Kedua penelitian tersebut menjelaskan bahwa dengan menggunakan model pembelajaran GI mampu meningkatkan hasil belajar dikarenakan pada model pembelajaran ini menuntut siswa memiliki kemampuan komunikasi yang baik dalam proses berkelompok. Hal tersebut sangat membantu bagi siswa yang kesulitan suatu materi dapat berkomunikasi langsung dengan teman dalam kelompok yang lebih memahami materi yang disampaikan.

(Agustina, 2018) juga menjelaskan penerapan metode GI ada peningkatan yang cukup signifikan. Hal tersebut dibuktikan dari penilaian awal 60\% siswa tuntas menyelesaikan KKM pada siklus yang pertama dan kedua pada penerapan model pembelajaran GI 90\% siswa tuntas dalam KKM. Selain itu penerapan model pembelajaran GI, mendapatkan respon baik dari siswa, dengan data sebanyak 95\% siswa menyatakan senang ketika penerapan
GI sebagai proses pembelajaran. Analisis tersebut menyimpulkan bahwa pembelajaran menggunakan GI adanya dampak yang baik pada peningkatan hasil belajar. Penelitian tersebut sejalan dengan (Astuti, Y. T., \& Haryono, 2017) menjelaskan pembelajaran GI dapat memberikan peningkatan. Pada penilaian awal siswa siklus pertama memiliki nilai rerata 69,63. Sedangkan setelah diterapkan pada siklus kedua, mengalami peningkatan yaitu nilai rerata sebesar 80 . Selain itu model pembelajaran GI juga mampu meningkatkan kefektivan siswa dengan data awal mendapatkan nilai $63,60 \%$ dan mengalami peningkatan setelah pembelajaran dengan GI menjadi $82,31 \%$. Analisis tersebut menyimpulkan bahwa pembelajaran menggunakan GI memiliki dampak yang positif dalam peningkatan belajar. Dua penelitian tersebut menjelaskan dampak positif yang dihasilkan dari pembelajaran GI adalah mampu mengeluarkan ide-ide dan gagasan baru melalui penemuan yang ditemukan, sehingga meningkatkan minat belajar siswa dalam mencari informasi baru.

Penelitian oleh (Novitasari, 2017) juga menunjukkan hasil yang positif. Pembelajaran dengan menggunakan GI siswa mampu meningkatkan hasil dari mata pelajaran ekonomi. Pada siklus pertama rerata siswa mendapat skor 67,71 dan pada siklus berikutnya menjadi 85,44. Hasil tersebut menunjukkan pembelajaran dengan menggunakan GI pada mata pelajaran ekonomi siswa dapat meningkatkan hasil. Sejalan dengan penelitian tersebut (Umantin, 2017)Pada penelitian menunjukan bahwa pembelajaran GI dapat meningkat hasil studi yang awalnya pada siklus pertama memperoleh skor rerata 67,56 selanjutnya menjadi 76,88. Hasil tersebut menunjukkan GI mampu meningkatkan dan menaikan hasil dari belajar siswa dengan penggunaan metode brainstorming. Metode tersebut memungkinan peserta didik menjadi lebih aktif terlibat dalam belajar, baik secara mandiri maupun dalam kelompok diskusi sesuai yang sampaikan (Wena, 2012). Pada saat melakukan presentasi siswa terlihat percaya diri, baik secara mandiri maupun dalam kelompok. Hal ini lah yang menjadikan kelebihan penerapan model GI dibandingkan model pembelajaran yang lain. 
(Priyono, 2017) menjelaskan model pembelajaran GI mampu memberikan kenaikan pada hasil studi. Dalam penelitian ini diterapkan sebanyak 3 siklus. Pada siklus pertama rerata skor siswa memperoleh skor 62, pada siklus kedua naik menjadi skor 81 dan disiklus ketiga lebih meningkat lagi dengan skor rerata 92. Hasil tersebut menunjukkan pembelajaran dengan GI mampu meningkatkan hasil studi. Penelitian lain oleh (Idrawati, 2018) juga menunjukan bahwa penelitian tersebut menjelaskan bahwa model dari pembelajaran GI siswa mampu meningkatkan hasil dari belajarnya dengan skor rerata awal 72,65 disiklus yang pertama. Setelah diberi pembelajaran disiklus yang kedua hasil belajar mengalami peningkatan dengan skor rerata 75,03. Analisis tersebut menyimpulkan pembelajaran GI berdampak positif .Penelitian yang sama juga didapatkan oleh (Fatmawati, 2019) menunjukan pembelajaran model GI, mampu hasil studi siswa dengan skor erata skor awal yaitu 62,5 pada siklus pertama dan mengalami peningkatan sebesar 88,89 pada siklus ke dua. Kedua peneltian ini memiliki cara yang sama yaitu memberikan evaluasi berupa soal tes tertulis pada setiap akhir putaran. Metode tersebut ternyata mampu meningkatkan hasil belajar siswa pada tiap siklusnya sehingga pada awal siklus banyak siswa yang tidak mencapai KKM, maka dalam siklus terakhir mampu banyak siswa yang melampaui KKM.

Dari beberapa artikel yang dijadikan acuan dalam studi literatur model GI banyak dikolaborasikan dengan metode lainnya sebagai upaya meningkatkan hasil belajar siswa khususnya di sekolah menengah atas pada mata pelajaran ekonomi. Selain itu kelebihan yang diperoleh ketika siswa belajar dengan GI adalah mampu melatih komunikasi siswa, baik itu selama berdiskusi di dalam kelompok maupun presentasi di depan kelas ketika mempresentasikan hasil pekerjaannya. Hal tersebut membantu siswa dalam meningkatkan skil kepemimpinan dan komunikasi yang dibutuhkan dalam hidup bermasyarakat.

\section{SIMPULAN DAN SARAN}

Berdasarkan kajian literatur dan hasil penelitian yang relevan diperoleh kesimpulan implementasi dari metode Group Invetigation pada pelajaran ekonomi memiliki pengaruh positif pada peningkatan hasil dari belajar siswa. Hasil analisis dari metode GI dapat memberikan peningkatan atau mengalami kenaikan yang cukup signifikan pada proses pembelajaran siklus ke dua maupun ketiga.

Hasil studi literatur tersebut menjelaskan bahwa penerapan dari model group investigation baik bagi siswa untuk meningkatkan hasil studi siswa. Oleh sebab itu dalam metode pembelajaran ini untuk memberikan peningkatan pada siswa yang baik perlu memilih mata pelajaran yang cocok, sehingga dengan dua siklus pembelajaran sudah menunjukkan hasil yang baik.

\section{DAFTAR PUSTAKA}

Adiasti, et al. (2016). The implimentation of inquiry learning with setting cooperative model type group investigation to enchance activity and learning outcomes for the fifth grade students. Journal of Research \&Method in Education (IOSR-JRME). Vol.6. Issue 3. PP 46-50.

Agustina, Y. (2018). Meningkatkan hasil belajar ekonomi dengan menggunakan model pembelajaran group investigation (gi) pada siswa kelas x di sma negeri 1 jeumpa. Jurnal Sain Ekonomi Dan Edukasi (JSEE), 5(1).

Aminah dan Salihati. (2012). Peningkatan proses dan hasil belajar siswa dengan model pembelajaran kooperatif tipe group investigation. Jurnal Lentera Vol. 12, No. 4.

Astuti, Y. T., \& Haryono, A. (2017). ). Implementasi Metode Brainstorming dalam Model Group Investigation pada Mata Pelajaran Ekonomi untuk Meningkatkan Keaktifan dan Hasil Belajar Siswa Kelas X IPS 3 SMAN 1 Batu. Jurnal Pendidikan Ekonomi, 10(2), 96-103.

Fatmawati, E. H. (2019). Peningkatan pemahaman pelaku ekonomi dalam kegiatan ekonomi menggunakan pembelajaran kooperatif model group investigation (gi) pada siswa kelas x ips-4 sma negeri 6 kediri semester 1 tahun pelajaran 2018/2019. LENTERA: Jurnal Pendidikan Dan Pengajaran, 9(4), 37-46.

Haibah, M. (2016). tasi model pembelajaran group investigation dengan permainan bendera pintar untuk meningkatkan minat belajar dan pemahaman konsep ekonomi siswa kelas $\mathrm{x}$ ipa 3 sman 1 jetis bantul tahun ajaran 2015/2016. Jurnal Pendidikan Dan Ekonomi, 5(6), 457-463.

Idrawati, I. (2018). Pembelajaran group investigasi meningkatkan hasil belajar siswa. JEKPEND: Jurnal Ekonomi Dan Pendidikan, 1(1), 17-26.

Novitasari, R. (2017). Penerapan metode pembelajaran group investigation dalam meningkatkan prestasi belajar siswa mata pelajaran ekonomi di sma oikonomia. Jurnal Pendidikan Ekonomi, 6(1).

Priyono, S. (2017). Peningkatan hasil belajar mata pelajaran ekonomi melalui penerapan model pembelajaran group investigation di kelas xi ma al fattah sumbermulyo. . Utility, 1(1), 1-10.

Rahayuni, K. M. (2016). Penerapan model pembelajaran kooperatif tipe group investigation untuk meningkatkan aktivitas dan hasil belajar ips siswa kelas viii di smp negeri 3 singaraja tahun pelajaran 2015/2016. Ekuitas: Jurnal Pendidikan Ekonomi, $4(2)$.

Sangadji, S. (2016). Implementation of cooperative learning with group investigation model to improve learning Achievement of vocational school students in Indonesia. International Journal of Learning \& 
Development, 6(1), 91-103.

Sugihartono. (2012). Psikologi pendidikan. Yogyakarta : UNY Press.

Tisara, M. S. (2016). Upaya meningkatkan hasil belajar ekonomi materi permasalahan ekonomi melalui pelaksanaan pembelajaran kooperatif tipe group investigation (gi) pada kelas x-6 sma negeri 1. Seuneubok Lada, 3(2), 40-54.

Trianto, M. (2009). Mendesain model pembelajaran inovatif-progresif. jakarta: Kencana.

Umantin, C. (2017). Aplikasi problem based learning dan group investigation dalam pembelajaran ekonomi di man malang. Konstruktivisme: Jurnal Pendidikan Dan Pembelajaran, 9(1), 135-146.

Wena, M. (2012). Strategi pembelajaran inovatif kontemporer. jakarta : Bumi Aksara. 